\title{
IWONA KULESZA-WORONIECKA
}

Białystok

\section{CUDZOZIEMCY W BIAŁYMSTOKU W OSIEMNASTYM WIEKU}

Wiek XVIII w dziejach Rzeczypospolitej szlacheckiej zaznaczył się m.in. licznym napływem cudzoziemców, którzy z różnych przyczyn, najczęściej zawodowych, czasowo lub na stałe osiedlali się na rozległych ziemiach Rzeczypospolitej. Intensywny napływ cudzoziemców uwarunkowany był kilkoma czynnikami. W 1. połowie XVIII w. napływ cudzoziemców do Polski związany był bezpośrednio z panowaniem dwóch monarchów saskich, Augusta II Mocnego i jego syna Augusta III Sasa. Wraz z objęciem tronu polskiego przez Augusta II zaczęli przybywać do Warszawy Saksończycy, którzy tutaj widzieli możliwość rozwoju swojej kariery zawodowej, a często także wiązali z Polską swoje życie osobiste. Kolejny etap napływu cudzoziemców związany był z panowaniem Stanisława Augusta Poniatowskiego. Jak zauważył Marek Grzegorz Zieliński w swojej pracy Cudzoziemcy w życiu codziennym Rzeczypospolitej doby stanisławowskiej: „Panowanie Stanisława Augusta miało przynieść, zgodnie z kierunkiem nakreślonym przez «Familię» u schyłku panowania Augusta III oraz przez sejm konwokacyjny i elekcyjny, wielopłaszczyznową przebudowę chylącego się ku upadkowi państwa polsko-litewskiego. Przed młodym monarchą stanęło zadanie o najwyższym stopniu złożoności. Okazało się bowiem, że aby wzmocnić system władzy wcześniej należy przebudować system prawny państwa, wzmocnić jego podstawy gospodarcze i co najważniejsze, dokonać całkowitego przemodelowania mentalności szlacheckiego społeczeństwa, którego większość obawiała się absolutystycznego zamachu na «złotą wolność». W tych warunkach szczególnego znaczenia zaczęli nabierać cudzoziemcy: ludzie nowi, niezwiązani z miejscową tradycją, stojący poza szlacheckim narodem, niosący w sobie pierwiastki, które były przydatne $\mathrm{w}$ dziele reform. Rzeczpospolita stanisławowska otworzyła się 
szeroko na cudzoziemców, a ich obecność stała się niejako programowo uzasadniona, wkalkulowana w proces budowy nowoczesnego państwa i narodu"1.

Szczególnie cenni w sytuacji zmian społeczno-ekonomicznych byli wszelkiego rodzaju specjaliści, których wiedza fachowa i umiejętności na polskim rynku pracy były wyjątkowo doceniane. Cudzoziemców szukających lepszych perspektyw, możliwości zrobienia kariery, czy zdobycia majątku przyciągały przede wszystkim duże ośrodki miejskie, a w pierwszej kolejności stolica. Jak słusznie zauważył Marek Grzegorz Zieliński: „Jedną z najbardziej zasadniczych przyczyn przyjazdu wielu wybitnych cudzoziemców do Warszawy była stała obecność dworu królewskiego. (...) Wizyta na dworze królewskim była niejako stałym punktem podróży cudzoziemców, a jednocześnie Warszawa w cieniu dworu królewskiego zaczęła oferować przybywającym coraz więcej atrakcji, stała się miastem godnym odwiedzenia, zapoznania z jego klimatem"2.

Wzrost atrakcyjności Warszawy jako miejsca wypraw turystycznych zaowocował pojawieniem się licznej rzeszy cudzoziemców, którzy stolicę Rzeczypospolitej uznali za godną odwiedzenia i poznania. Warszawa, podobnie jak Petersburg, stała się punktem zainteresowania młodych Europejczyków, którzy podróż po dalekich krajach traktowali jako nieodzowny element swojej edukacji ${ }^{3}$.

Warszawa przyciągała również z powodu potencjalnych miejsc pracy. Rozwój stolicy dawał nadzieję na pracę zarówno osobom wysoko wykwalifikowanym, jak również tym, którzy nie mając pieniędzy i kwalifikacji liczyli na zrobienie kariery i zdobycie majątku. Jak ustalił Adam Walaszek, „Migranci stanowili część rozwoju wszystkich miast - widać ich było od Gdańska i Berlina po Marsylię i Norwich. $\mathrm{Z}$ jednej strony, znaczna część społeczeństwa zmuszona była do przemieszczeń, przynajmniej regionalnych, $\mathrm{z}$ drugiej - pomiędzy miejskimi i wiejskimi elitami oraz elitami różnych miast istniały rozmaite powiązania. Migranci kierowali się ku szczególnie dynamicznie rozwijającym się obszarom, ku rosnącym powoli miejskim centrom produkcji”". Podobne stanowisko reprezentują inni badacze, którzy zgodnie twierdzą, że to miasta - w głównej mierze - bardzo chętnie przyjmowały

1 M. G. Zieliński, Cudzoziemcy w życiu codziennym Rzeczypospolitej doby stanisławowskiej, Bydgoszcz 2004, s. 23.

2 Ibidem, s. 64

3 Przykładem może być podróż lorda Pembroke, najstarszego syna księcia Malborough, który w roku 1778 w towarzystwie historyka Williama Coxe’a podróżował po Polsce, a następnie udał się do Rosji.

4 A. Walaszek, Migracje Europejczyków 1650-1914, Kraków 2007, s. 54. 
emigrantów, a władze niektórych miast prowadziły konsekwentną politykę, której celem było kontrolowanie napływu nowych obywateli ${ }^{5}$.

Jednym z miast Rzeczypospolitej, które wyjątkowo mocno przyciągało cudzoziemców była Warszawa. Szczególnie intensywny napływ cudzoziemców stolica zawdzięcza elekcji Stanisława Augusta Poniatowskiego. Jak słusznie zauważył Marek Zieliński: „Nowo otwarty dwór królewski wymagał blasku i świeżości. Miał być wszak głównym ośrodkiem reformatorskim. Powszechnie było wiadomo w Europie, że dwór warszawski, będąc w stadium odtwarzania po epoce saskiej, jest niezwykle chłonnym potrzebującym ludzi zdolnych i energicznych. Stąd też nie tylko w wyniku zabiegów króla przybywali do Polski liczni przedstawiciele szeroko pojętego świata kultury i sztuki”6.

Liczne grono artystów, rzemieślników, wykwalifikowanych pracowników manufaktur przybywało do Polski z inicjatywy magnatów, którzy częściowo wzorując się na królu, a częściowo inspirowani wzorcami zachodnioeuropejskimi dążyli do rozwoju swoich dworów, rezydencji i miast prywatnych. Badając problematykę napływu cudzoziemców do Rzeczypospolitej w czasach Stanisławowskich Marek Zieliński zauważył: „Aczkolwiek dwór królewski dominował i to w sposób znaczący, to jednak nie można nie zauważyć, że bardzo ważnym czynnikiem recepcji cudzoziemców był rozwój mecenatu magnackiego, przede wszystkim: Augusta, Izabeli i Kazimierza Czartoryskich, Izabeli z Czartoryskich Lubomirskiej, Karola Radziwiłła, Heleny z Przeździeckich Radziwiłłowej, Antoniego Tyzenhauza, Jana Klemensa Branickiego, Michała Poniatowskiego, Anny z Sapiehów Jabłonowskiej, Ludwika Tyszkiewicza, Michała Kazimierza Ogińskiego, Sułkowskich z Rydzyny, biskupa Ignacego Massalskiego. Każdy z nich sprowadził bądź przygarnął przybyłych nieco wcześniej, często za poprzedniego panowania, po kilkunastu, a nawet kilkudziesięciu cudzoziemców"7. Miejscem, do którego w głównej mierze docierali obcokrajowcy była rezydencja Jana Klemensa Branickiego.

Marek Zieliński uważa, że podobnie jak na dworze królewskim „Na dworach magnackich również rojno było od cudzoziemców. Na pierwsze miejsce wybijał się pod tym względem Białystok Jana Klemensa Branickiego".

5 K. Mikulski, Pułapka niemożności. Społeczeństwo nowożytnego miasta wobec procesów modernizacyjnych (na przykładzie Torunia w XVII i XVIII wieku), Toruń 2004, s. 306-307.

6 M. G. Zieliński, op. cit., s. 64.

7 Ibidem, s. 65.

8 Ibidem, s. 82. 
W dotychczasowych badaniach odnoszących się do dziejów miasta Białegostoku zabrakło miejsca na wnikliwą i pełną analizę dotyczącą udziału cudzoziemców w dziejach osiemnastowiecznego miasta. Jedynie nieliczni badacze zajmujący się działalnością Jana Klemensa Branickiego ${ }^{9}$ dostrzegają obecność cudzoziemców w strukturach społecznych dworu i miasta. Głównie badacze historii kultury i sztuki zauważyli i docenili wkład artystów cudzoziemskich $\mathrm{w}$ rozwój miasta ${ }^{10}$. Również specjalizująca się $\mathrm{w}$ historii kultury materialnej Elżbieta Kowecka dostrzegła duży wpływ artystów cudzoziemskich na rozwój dworu Jana Klemensa Branickiego jak również i miasta Białegostoku w XVIII w. ${ }^{11}$ Pisząc o materialnych aspektach funkcjonowania dworu hetmańskiego, Elżbieta Kowecka wielokrotnie podkreślała wkład twórców cudzoziemskiego pochodzenia w powstanie i funkcjonowanie rezydencji białostockiej. Trudno więc zrozumieć milczenie historyków regionu, zwłaszcza tych zajmujących się strukturą społeczną miasta, którzy dość konsekwentnie pomijają informacje dotyczące pobytu cudzoziemców w Białymstoku ${ }^{12}$, analizę struktury ograniczają jedynie do podziałów religijnych (podział ludności na chrześcijańską i żydów). Pewną zmianę w postrzeganiu mieszkańców Białegostoku przyniosły ostatnie prace. Sporo informacji na temat pobytu cudzoziemskich artystów w Białymstoku zawdzięczamy badaniom Aliny Żórawskiej-Witkowskiej ${ }^{13}$. O cudzoziemcach, którzy odwiedzali Białystok przejazdem pisze zaś Bernadetta M. Puchalska-Dąbrowska ${ }^{14}$. Pobyt Francuzów i Anglików w Białymstoku był również przedmiotem moich zainteresowań ${ }^{15}$.

Źródła do badań problematyki pobytu cudzoziemców w Białymstoku są rozproszone i trudno na ich podstawie w pełni ocenić wielkość grupy badawczej,

9 Szerszych badań dotyczących działalności Izabeli Branickiej w Białymstoku jak dotychczas nie prowadzono.

10 por. S. Dąbrowski, Dwieście lat teatru w Białymstoku, Białystok 1979; A. Bartczakowa, I. Malinowska, Pałac Branickich, Warszawa 1974.

11 E. Kowecka, Dwór „najrządniejszego w Polszcze magnata”, wyd. II, Warszawa 1993.

12 por. A. Sztachelska-Kokoczka, Białystok za pałacowa brama, Białystok 2009; A. Oleksicki, Rozwój przestrzenny i struktura ludności Białegostoku, [w:] Studia nad społeczeństwem i gospodarką Podlasia w XVI-XVIII wieku, red. A. Wyrobisz, Białystok 1981, s. 31-90; M. J. Lech, Białystok - miasto i jego mieszkańcy w XVIII wieku, „Rocznik Białostocki” 1966, t. 6, s. 441-454.

13 A. Żórawska-Witkowska, Muzyka na dworze Jana Klemensa Branickiego, [w:] Dwory magnackie w XVIII wieku, Warszawa 2005, s. 221-244.

14 B. M. Puchalska-Dąbrowska, Białystok Branickich w relacjach cudzoziemców, [w:] Mecenat artystyczny Branickich, red. M. Olesiewicz, B. Puchalska-Dąbrowska, Białystok 2004, s. 43-55.

15 I. Kulesza-Woroniecka, Anglicy i Francuzi w osiemnastowiecznym Białymstoku, [w:] Anglosasi, Francuzi i Polacy - wzajemne inspiracje w literaturze, kulturze i języku, red. D. Guzowska i M. Kamecka (artykuł w druku). 
z jaką mamy do czynienia. Część informacji dotycząca pobytu i działalności cudzoziemców w Białymstoku została zaczerpnięta z korespondencji Branickich, ich urzędników i współpracowników ${ }^{16}$. Inne informacje pochodzą $\mathrm{z}$ rachunków Branickich, wiele zaś cennych informacji źródłowych i objaśnień zawierają tzw. Teki Glinki. „Jest to zbiór prac, notatek, a przede wszystkim wypisów archiwalnych, które Glinka gromadził przez wiele lat z przeznaczeniem do wielkiego dzieła mającego dotyczyć mecenatu artystycznego Branickiego. Są to materiały wprost nieocenione, Glinka bowiem dzięki długoletniej pracy archiwisty jak nikt znał akta dotyczące tego tematu, jak nikt też potrafił odczytać niesłychanie nieczytelne odręczne uwagi hetmana, którymi ten opatrywał często napływającą doń korespondencję. (...) czynił też liczne poszukiwania, by rozwiązać - występujące w listach - nazwiska artystów, rzemieślników, kupców itp." ${ }^{17}$.

Uzupełnieniem tej obszernej bazy źródłowej są pamiętniki, wspomnienia i relacje z podróży cudzoziemców, którzy w czasie swoich peregrynacji po Polsce odwiedzili Białystok. Zachwyceni wspaniałością rezydencji oraz czystością miasta - co w ówczesnych czasach zdaje się było rzadkością - pozostawili w swych wspomnieniach niezwykle pochlebne opinie na temat siedziby Branickich ${ }^{18}$.

Pierwsi cudzoziemcy w Białymstoku zapewne pojawili się już pod koniec XVII w. Związane to było $\mathrm{z}$ działalnością wojewody podlaskiego, Stefana Mikołaja Branickiego, który postanowił dokonać przebudowy zamku obronnego ufundowanego ok. 1570 r. przez Piotra Wiesiołowskiego. Realizacją planów architektonicznych Stefana Mikołaja Branickiego od roku 1691 zajął się architekt pochodzenia holenderskiego, Tylman z Gameren ${ }^{19}$. Trudno przypuszczać, aby prace prowadzili miejscowi rzemieślnicy, gdyż brakowało tu wielu specjalistów zajmujących się rzemiosłem artystycznym, i to oni zapewne jako pierwsi trafili do Białegostoku. Kolejna przebudowa pałacu, prowadzona już z inicjatywy Jana Klemensa Branickiego, rozpoczęła się około roku 1726. Dzięki staraniom hetmana do Białegostoku przybył architekt saski Jan Zygmunt Deybel, a wraz z nim grono

16 Korespondencja Branickich i ich współpracowników jest rozproszona w kilku różnych zespołach archiwalnych, najwięcej listów znajduje się w Archiwum Roskim, przechowywanym w Archiwum Głównym Akt Dawnych (dalej: AGAD), część w Archiwum Radziwiłłów w dziale korespondencja również przechowywanym w AGAD, szczątkowe pozostałości zaś w Archiwum Branickich z Białegostoku (również AGAD) i Archiwum Anny z Potockich Branickiej (także AGAD). E. Kowecka, op. cit., s. 8.

18 por. Polska stanisławowska w oczach cudzoziemców, t. 1-2, oprac. W. Zawadzki, Warszawa 1963; F. Schultz, Podróż Inflantczyka z Rygi do Warszawy i po Polsce w latach 1791-1793, Warszawa 1963.

Teki Glinki 92, s. 5, 6, 8 . 
rzemieślników, którzy mieli zająć się dalszą realizacją projektów przebudowy pałacu. Od tego momentu cudzoziemcy w Białymstoku stali się niezbędni. Będąc wysokiej klasy fachowcami zajęli ważne miejsce w życiu dworu i miasta. Wśród rzemieślników związanych z budownictwem, którzy zostali zatrudnieni przy pracach murarskich, stolarskich czy też hydraulicznych, w głównej mierze znajdowali się fachowcy, którzy przybyli z Niemiec, Prus i Czech. Znalazł w Białymstoku w roku 1729 zatrudnienie Saksończyk, architekt Joachim Daniel Jauch ${ }^{20}$. Przez wiele lat naprawą urządzeń wodnych zajmował się rzemieślnik pochodzący z Niemiec, Hempel, który w latach 1736-1763 nadzorował białostockie studnie i fontanny ${ }^{21}$. W roku 1757 został przez Branickiego zaangażowany do prac kamieniarskich Matys, kamieniarz z Czech, „który nie tylko od piaskowanego kamienia umie robotę, ale i od marmuru"22.

$\mathrm{Na}$ stałe swoje losy z rodziną Branickich związał artysta malarz Antoni Herliczka. Powszechnie uważano, że pochodził z Czech, lecz wątpliwości co do jego pochodzenia przedstawił ks. Jan Nieciecki, twierdząc, iż należy uważać, że wywodził się z monarchii habsburskiej ${ }^{23}$. Antoni Herliczka do prac na rzecz dworu Branickiego w Warszawie został zaangażowany w roku 1749 . Wtedy to Branicki powierzył mu odtworzenie malowideł na murze ogrodu przy pałacu warszawskim. Malarz do Białegostoku musiał przybyć najpóźniej ok. 1751 r. ponieważ zaczął prace malarskie w białostockim kościele. Od tego czasu aż do śmierci Herliczka związany był z dworem Branickich w Białymstoku. Za zgodą hetmana 17 lutego 1754 r. ożenił się z Marianną Paszkowską, tu urodziły się i wychowały jego dzieci. Ostatnią pracą na rzecz Izabeli Branickiej, która po śmierci Jan Klemensa nadal zatrudniała malarza, było malowanie obrazu do kościoła w Dolistowie w roku $1792^{24}$. Tak więc Antoni Herliczka związał swe losy z Branickimi na ponad czterdzieści lat, a jego rodzina dołączyła do grona mieszkańców Białegostoku.

Szczególne miejsce na dworze Branickich zajmowali artyści i rzemieślnicy. W roku 1771, gdy Białystok w sumie liczył 1845 stałych mieszkańców, ok. 200 z nich stanowili rzemieślnicy i artyści ${ }^{25}$. Szczególnie liczni byli Francuzi. Należy tu wymienić chociażby kilku spośród nich. Pierre Ricaud de Tirreguille

20 Teki Glinki 315, s. 64.

21 Teki Glinki 315, s. 87.

22 Teki Glinki 335, s. 3.

23 por. szerzej: ks. J. Nieciecki, Kim był Antoni Herliczka?, „Białostocczyzna” 1991, nr 3, s. 12-16.

24 Teki Glinki 316, s. 47.

25 E. Kowecka, op. cit., s. 53. 
(ur. 1725, zm. po 1772), francuski inżynier i architekt, w Polsce przebywał w latach 1752-1763. W Białymstoku zajmował się przede wszystkim nadzorem technicznym nad zakładaniem machin wodnych, sadzawek i fontann ${ }^{26}$. Branicki określał go w swojej korespondencji mianem „mój inżynier”27. Prace hydrauliczno-inżynieryjne w Białymstoku Ricaud de Tirreguille prowadził w latach 1753-1760 $0^{28}$. Ponadto $\mathrm{z}$ białostockim dworem byli związani: Andre Le Brun (1737-1811), rzeźbiarz 1768-1795 i nadworny artysta króla Stanisława Augusta Poniatowskiego, Piotr Coudray - francuski nadworny rzeźbiarz Augusta III, który w latach 1761-1763 wykonał pomnik Stefana Czarnieckiego w Tykocinie na zlecenie Branickiego, francuski portrecista Louis Maretaeu (1715-1804), Jean Baptista Pillement (1728-1808) i Augustyn Sylwester Mirys (1700-1790), który od roku 1731 przebywał w Polsce u Jabłonowskich, a od 1750 aż do swojej śmierci - u Branickich w Białymstoku ${ }^{29}$.

Obok malarzy, architektów i rzemieślników, których potrzebowało rozwijające się miasto, zaczęli do Białegostoku przybywać również przedstawiciele innych cenionych i poszukiwanych profesji. Hetman Jan Klemens Branicki, który miał ambicje uczynić z Białegostoku silny ośrodek kulturalny i centrum życia artystycznego na Podlasiu, wkrótce po ukończeniu najważniejszych prac budowlanych w pałacu zapragnął posiadać - jak na dwór magnacki przystało - własną orkiestrę, operę i balet. W celu realizacji swoich planów artystycznych był zmuszony zaangażować liczną grupę artystów - cudzoziemców, głównie pochodzenia włoskiego.

Analizującazagadnieniezainteresowań muzycznych Jana Klemensa Branickiego Alina Żórawska-Witkowska ustaliła, że początki dworskiej kapeli Branickich sięgają roku 1730. Tak o tym pisze w swoim artykule: „W dzień po wyjeździe z Białegostoku Augusta II, 29 września (...) «dywertowano» się tam tańcami, a 6 grudnia żałobna tym razem muzyka uświetniła pogrzeb pierwszej żony Branickiego - Katarzyny z Radziwiłłów. W obu tych wypadkach chodziło niewątpliwie o występy dworskiej kapeli Branickiego, w każdym razie zespół taki był już na utrzymaniu chorążego wiosną 1732 roku i nosił barwę koloru zielonego" ${ }^{30}$. W roku 1742 kapela dworska liczyła dziewięciu muzyków i wnioskując po brzmie-

26 Teki Glinki 330, s. 1-2.

27 Teki Glinki 320.

28 I. Kulesza-Woroniecka, The English and French in $18^{\text {th }}$-century Białystok, [w:] Inspirations: English, French and Polish Cultures, ed. by D. Guzowska and M. Kamecka, Białystok 20011, s. 234.

29 Więcej informacji na ten temat w: ibidem, s. 234-235.

30 A. Żórawska-Witkowska, op. cit., s. 223. 
niu ich nazwisk należy przypuszczać, że byli to Polacy. Pierwszym artystą cudzoziemskim, którego zatrudnienie w kapeli dworskiej mamy źródłowo potwierdzone, był sławny w owym czasie skrzypek włoski Pio. Wcześniej ów muzyk działał na dworze wojewody krakowskiego, Teodora Lubomirskiego. Po śmierci wojewody wdowa rozwiązała kapelę dworską, a włoskiego koncertmistrza poleciła hetmanowi Branickiemu. Tak więc wraz z przybyciem do Białegostoku „wiolinisty sławnego" ${ }^{\prime 31}$ zaczęli na dwór Branickich przybywać również inni cudzoziemscy artyści. W roku 1749 do Białegostoku przybyły dwie pierwsze - nieznane nam z imienia i nazwiska - włoskie śpiewaczki ${ }^{32}$. W latach sześćdziesiątych przybyli tutaj dwaj inni śpiewacy włoscy, Constantino Compassi i Filippo Laschi ${ }^{33}$. Artyści ci byli tylko czasowo związani z Białymstokiem. W roku 1750 przybył na dwór Branickiego kompozytor wiedeński Jan Melchior Pichler, wraz z nim przyjechały również jego dwie córki - śpiewaczki Maria Magdalena i Joanna Pichlerówny. Losy rodziny Pichlerów zostaną na trwałe związane z dworem Branickich. Jan Melchior zostaje zatrudniony $\mathrm{w}$ charakterze kapelmistrza aż do końca istnienia kapeli dworskiej (1750-1772) ${ }^{34}$. Jego córka Joanna w roku 1751 zostaje żoną muzyka Jana Majera. Zapewne młodsza Maria Magdalena na koszt Branickiego kształci się w roku 1757 w Warszawie u mistrza śpiewu, Pasqualino Bruscoliniego ${ }^{35}$. Z dworem Branickich pozostaje do końca życia Izabeli Branickiej i funkcjonowania dworu, o czym może świadczyć fakt, iż w roku 1796 mieszka nadal w Białymstoku i występuje wśród dworzan Izabeli Branickiej ${ }^{36}$.

Wraz z rozwojem kapeli dworskiej Branicki zapragnął również zorganizować własny teatr muzyczny, gdzie podobnie jak na dworze królewskim miały być wystawiane niezwykle wówczas modne opery włoskie i francuskie. Organizację teatru Branicki rozpoczął od stworzenia własnego zespołu baletowego. W tym celu w roku 1762 zatrudnił włoskiego baletmistrza, Antonia Putiniego. Putini zaraz rozpoczął edukację baletową dwanaściorga dzieci (sześciu chłopców i sześciu dziewczynek) ${ }^{37}$. W celu związania baletmistrza z miastem w roku 1763 rozpoczęto budowę domu, w którym miał zamieszkaćs ${ }^{38}$. Putini zamieszkał w Białymstoku wraz z żoną. Tutaj urodziło się jego sześcioro dzieci. Śmierć hetmana i decyzja wdowy

\footnotetext{
31 Teki Glinki 315, s. 138.

32 A. Żórawska-Witkowska, op. cit., s. 226.

33 Ibidem, s. 227.

34 Teki Glinki 336, s. 2, 3v.

35 Teki Glinki 318, s. 1.

36 Teki Glinki 315, s. 245.

37 Teki Glinki 333, s. 1.

38 Teki Glinki 357, s. 6-9.
} 
o likwidacji baletu skłoniły Putiniego do opuszczenia naszego miasta. Obok artystów włoskich, którzy na dłużej związali się z teatrem hetmańskim pojawiali się wybitni śpiewacy, dla których Białystok był jedynie jednym z wielu miast leżących na trasie ich europejskich podróży. I tak imieniny hetmanowej Izabeli (Elżbiety) Branickiej w dniu 21 października 1765 r. uświetniło wystawienie opery, w której wystąpili będący czasowo w Białymstoku Filippo Laschi, Antonia Bernasconi, Antonio Valletti i związana z dworem białostockim na stałe Magdalena Pichler. W roku 1766 przybył do Białegostoku z Florencji śpiewak włoski, Antonio Boscoli. Na początku roku 1767 Antonia Bernasconi i Filippo Laschi opuścili Białystok, ale już w marcu 1767 na dworze hetmana pojawili się kolejni znani śpiewacy włoscy. Byli to Caterina Ristorini i Michele del Zanca. Przebywali tutaj do roku 1770 i w tymże roku wzięli ślub na dworze hetmana, a następnie udali się do Londynu, gdzie w latach 1770-1771 występowali w słynnym Kihg's Theatre ${ }^{39}$. Caterina Ristorini i Michele del Zanca to ostatni wielcy artyści operowi, których gościł osiemnastowieczny Białystok. Po śmierci hetmana w roku 1771 kapela dworska i teatr zostały zlikwidowane i artyści masowo zaczęli opuszczać Białystok. Tylko nieliczni, jak chociażby wspomniana wcześniej Magdalena Pichler, pozostali na dworze Pani Krakowskiej.

Obok artystów i rzemieślników, którzy swą pracą umilali życie magnata i nadawali blask i świetność jego rezydencji, na dworach zatrudniani byli również cudzoziemcy - specjaliści z innych dziedzin. Szczególnie poszukiwani byli lekarze. $Z$ powodu niedoboru polskich adeptów studiów medycznych, magnaci chętnie na swoich dworach zatrudniali lekarzy cudzoziemców, którzy niejednokrotnie lepiej wykształceni niż polscy medycy, cieszyli się znakomitą sławą i chętnie byli zatrudniani w Rzeczypospolitej.

Również na dworze białostockim Branickich praktykowali liczni lekarze cudzoziemcy. Szczególnie trzej spośród nich na trwałe związali się z naszym miastem. Byli to Michał Klement, Jakub Feliks de Michelis i Antoni Issauart. Wszyscy oni przez wiele lat służyli na dworze jako nadworni lekarze Jana Klemensa, a później także Izabeli Branickiej. Ze względu na swe wysokie kwalifikacje często byli wykorzystywani także przez magnatów z sąsiednich rezydencji (Annę Jabłonowską w Siemiatyczach, Sapiehów w Boćkach, Starzeńskich w Strabli). Swoimi umiejętnościami zawodowymi służyli także miejscowej ludności, czego dowody odnajdujemy w źródłach.

39 A. Żórawska-Witkowska, op. cit., s. 241. 
Jednym z pierwszych lekarzy cudzoziemców, który przybył do Białegostoku, był Węgier Michał Klement. W roku $1739 \mathrm{z}$ rekomendacji związanego z dworem drezdeńskim Neubourga przybył sprowadzony przez Krystynę Sapieżynę Michał Klement ${ }^{40}$, który jeszcze w roku 1746 leczył jej córkę Teresę. Nie wiemy, kiedy dokładnie przeniósł się do Białegostoku, lecz zapewne ok. 1740 r. ponieważ w tym to roku Rozalia Chodkiewiczowa prosiła w jednym z listów do Jana Klemensa Branickiego o przysłanie doktora Klementa do jej chorego syna do Supraśla ${ }^{41}$. O tym, że Michał Klement na stałe osiadł w Białymstoku może świadczyć wzmianka z roku 1772 o posiadanych tutaj przez niego budynkach gospodarczych ${ }^{42}$. Klement jako zasłużony medyk hetmana został ujęty w jego testamencie, a usługi swe na rzecz dworu Branickich i mieszkańców Białegostoku pełnił aż do swojej śmierci w roku 1787. Podobnie długi i trwały był związek z naszym miastem innego lekarza pracującego na dworze Branickich - Jakuba Feliksa Michelisa. Przybył on do Polski z Prus. Posadę felczera na dworze Izabeli Branickiej objął w roku $1790^{43}$. Szybko zaczął prowadzić szeroko zakrojoną działalność medyczną na rzecz miejscowej ludności. Zainteresowały go nowinki medyczne związane z możliwością przeprowadzania szczepień przeciwko ospie. Zaczął on eksperymentalne szczepienia poddanych w dobrach podlaskich Branickiej, a także poza nimi. Ta nowatorska działalność medyczna spowodowała, że popadł w konflikt z Józefem Ossolińskim, właścicielem Turośni Kościelnej, na terenie której również prowadził szczepienia ${ }^{44}$. Jakub Michelis założył w roku 1800 (1811) Instytut Akuszerek, który działał do 1836 r., był też autorem uznanego podręcznika pt. Krótka nauka dla akuszerek po prowincjach ${ }^{45}$. Pracę swą podpisał jako lekarz - chirurg nadworny Izabeli Branickiej ${ }^{46}$. Po śmierci Izabeli Branickiej w roku 1808, Jakub Michelis pozostał w Białymstoku i nadal prowadził swoją praktykę lekarską. Zmarł w roku 1820.

Równie uznanym i zasłużonym medykiem był Antoni Issauart, lekarz Branickich, a następnie nadworny lekarz króla Stanisława Augusta Poniatowskiego. Był on jednym z nielicznych specjalistów w dziedzinie profilaktyki ospy. Brał

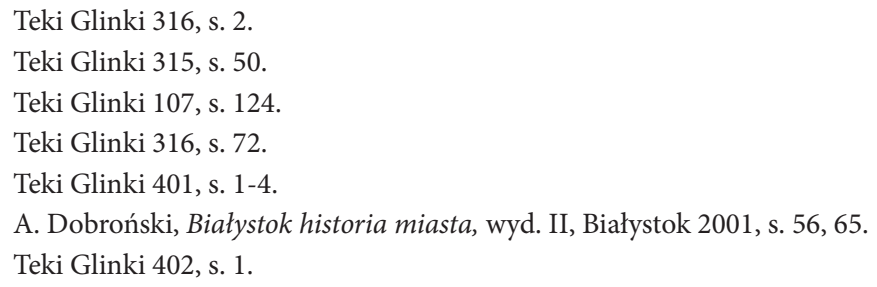


udział $\mathrm{w}$ konsylium poświęconym problematyce szczepień przeciwko ospie, a także sam je przeprowadzał ${ }^{47}$.

O tym, jak bardzo byli potrzebni i poszukiwani pracownicy pochodzenia cudzoziemskiego, a zwłaszcza Francuzi, najlepiej świadczy fakt, iż nie mogąc zdobyć odpowiednich fachowców na terenie Rzeczypospolitej, „Jan Klemens Branicki miał w Paryżu swego agenta Matisse’a, który rekrutował tamże chętnych do służby dworskiej, a następnie ekspediował do Polski wraz z kupcem Jeanem Rousseau"48.

Spośród specjalistów wywodzących się z Francji najbardziej poszukiwani i co za tym idzie cenieni, byli kucharze. Jan Klemens Branicki, mimo posiadania znakomitych kucharzy, stale poszukiwał nowych. Wielokrotnie zwracał się do swoich znajomych i oficjalistów z prośbą o wyszukanie mu kucharza, koniecznie Francuza, i kilkakrotnie udało mu się takiego kuchmistrza zaangażować. W latach 1756-1765 szefem kuchni Branickich był niejaki Roux, tak bardzo ceniony przez swego pracodawcę, iż ten kazał w roku 1756 sprowadzić z Paryża specjalne naczynia, które miały francuskiemu kuchmistrzowi ułatwić pracę $e^{49}$.

W roku 1760 przybyło do Polski dwóch kucharzy Francuzów, jeden zamówiony przez Branickiego, a drugi przez jego siostrę Elżbietę Lubomirską ${ }^{50}$.

W roku 1766 agent Branickiego w Paryżu, wspomniany wcześniej Matisse donosił hetmanowi, iż udało mu się namówić na wyjazd do Polski jednego z najlepszych tutejszych kuchmistrzów (posiadającego szczególny talent do przyrządzania wyśmienitych deserów). Znakomitego kuchmistrza w drogę do Warszawy zabrał wspomniany już kupiec i dostawca Branickich - Józef Rousseau ${ }^{51}$. Również do posług osobistych chętnie zatrudniani byli cudzoziemcy. Kamerdynerem Jana Klemensa Branickiego był Francuz Gerard. Także w pracach kancelarii Branickiego brali udział cudzoziemcy. Przez wiele lat sekretarzem tzw. Ekspedycji cudzoziemskiej był Szwajcar Jan Beck, a od roku 1758 zastąpił go Czech, ksiądz Antoni Betański ${ }^{52}$, który po śmierci hetmana pozostał nadal na dworze Branickich w charakterze plenipotenta Izabeli.

47 M. G. Zieliński, op. cit., s. 164.

48 Ibidem, s. 77.

49 E. Kowecka, op. cit., s. 49.

50 Ibidem.

51 Ibidem.

52 Ibidem, s. 45. 
Należy pamiętać, że cudzoziemcy pojawiali się w Białymstoku nie tylko jako poszukiwani pracownicy o wysokich kwalifikacjach, lecz również - i to dość często - jako turyści pragnący poznać to miasto. I tak w roku $1757 \mathrm{w}$ Białymstoku przebywał poseł francuski L’Hospital ${ }^{53}$. W tym samym roku w naszym mieście przebywała Francuzka - baronowa La Fort ${ }^{54}$. Znajomość Branickich z baronową trwała znacznie dłużej, o czym może świadczyć fakt, iż w roku 1784 Izabela Branicka wysłała jej pieniądze do Paryża ${ }^{55}$.

W roku 1758, podczas nieobecności Jana Klemensa Branickiego, Białystok odwiedził poseł angielski George Keith - celem jego wizyty było zwiedzenie miasta $^{56}$. W liście z roku 1762 swoją wizytę zapowiedział Marc - Antoine d’Argenson de Paulmy, poseł francuski, który do Białegostoku miał przybyć wraz z nuncjuszem apostolskim ${ }^{57}$. W $1763 \mathrm{r}$. Braniccy oczekiwali przybycia hrabiego Marcy ${ }^{58}$.

Śmierć hetmana Branickiego w roku 1771 spowodowała czasowe zmniejszenie wizyt obcokrajowców, lecz w kilka lat później ponownie pojawili się podróżnicy cudzoziemscy zainteresowani zwiedzaniem białostockiego pałacu. W roku 1778 do Białegostoku przybyli William Coxe - brytyjski historyk i guwerner, oraz jego podopieczny lord Pembroke, syn księcia Malborough. Obaj odbywali podróż edukacyjną, której celem był Petersburg, lecz za słuszne uznali odwiedzenie również leżącego na trasie podróży miasta Branickich. W tym samym roku Białystok odwiedził również szwajcarski astronom i matematyk, Johann Bernuoilli. W Białymstoku zatrzymał się także w roku $1784 \mathrm{w}$ drodze do Wilna Jan Jerzy Forster, niemiecki podróżnik i literat. Forster jako baczny obserwator i znakomicie posługujący się piórem pozostawił opis odwiedzanego dworu Branickiej. Jego uwagę zwrócili przede wszystkim dworzanie i rezydenci, ludzie różnych narodowości, stale lub czasowo przebywający na dworze Pani Krakowskiej. Wśród nich znaleźli się nadworni lekarze Branickiej - Dunker, Issauart i Kijeński, dawny przyboczny lekarz hetmana - Klement, inżynier i oficer Francuz de Pauli, nuncjusz Archetti i hrabina Melfort ${ }^{59}$. To grono zrobiło duże wrażenie na wytrawnym podróżniku, który nie spodziewał się spotkać tu tak wielu cudzoziemców.

Białystok odwiedzali również monarchowie. Przebywali tutaj August II Mocny, August III Sas i Stanisław August Poniatowski - brat Izabeli Branickiej.

Teki Glinki 101, s. 1.

Teki Glinki 315, s. 182.

Teki Glinki 365, s. 1.

Teki Glinki 339, s. 11.

Teki Glinki 315, s. 165.

Teki Glinki 381, s. 3.

G. Forster, Dziennik podróży po Polsce, [w:] Polska stanisławowska..., t. II, s. 73-75. 
W roku 1780 przebywał tutaj podróżujący incognito cesarz austriacki Józef II. W 1782 białostocki pałac gościł księcia Pawła, późniejszego cara Rosji. W związku $\mathrm{z}$ wizytą Pawła nie tylko przygotowano odpowiednio pałac, lecz również wokół Białegostoku dokonano niezbędnych napraw dróg i mostów ${ }^{60}$. Odwiedził Białystok będący tu przejazdem król pruski, Fryderyk Wilhelm III. Przez pewien czas w roku 1798 gościem Izabeli Branickiej był także wypędzony z kraju Ludwik Burbon - późniejszy król Francji Ludwik XVIII. W XVIII w. Białystok gościł przedstawicieli dyplomatycznych Anglii, Austrii, Danii, Francji, Hiszpanii, Holandii, Prus i Rosji ${ }^{61}$. Zdarzali się też goście spoza Europy. W roku 1793 wraz z królem Stanisławem Augustem Poniatowskim przybył do Białegostoku Amerykanin Lewis Littlepage ${ }^{62}$.

Zaprezentowana egzemplifikacja wyraźnie wskazuje, iż osiemnastowieczny Białystok był miejscem często odwiedzanym przez cudzoziemców. Miasto przyciągało obcych stanowiąc dla nich atrakcyjne miejsce pracy, a często i życia dla nich samych i ch rodzin. Jako fachowcy przybywali do nas artyści i rzemieślnicy z Francji, Włoch, Saksonii, Czech, Prus, a nawet Holandii. Przybywali na kilka, kilkanaście lat, a często osiedlali się tutaj na stałe. Cudzoziemcy pozostawiali po sobie efekty swojej pracy, których część możemy obserwować do dnia dzisiejszego.

W 2. połowie XVIII w. coraz częściej sława białostockiego pałacu przyciągała turystów pragnących zwiedzić Wersal Północy. W tym czasie jako turyści do miasta docierali głównie spragnieni wiedzy Anglicy, chociaż przedstawiciele innych nacji również chętnie gościli w naszym mieście.

Reasumując, należy wyraźnie podkreślić, iż bez aktywnego udziału cudzoziemców intensywny rozwój Białegostoku w XVIII w. byłby zupełnie niemożliwy, a i sława tego miasta byłaby znacznie skromniejsza, gdyby nie pochlebne opisy jego atrakcji, jakie w swych relacjach pozostawili cudzoziemcy.

6o Teki Glinki 41, s. 30.

61 A. Dobroński, op. cit., s. 49.

62 Teki Glinki 102, s. 5, 12. 


\title{
Foreigners in the 18th century Bialystok
}

\begin{abstract}
Summary
Foreigners appeared in Bialystok at the beginning of the 18th century. It was Jan Klemens Branicki, the owner of this small town, who initiated their arrival in Bialystok. First to come there were mainly craftsmen specializing in building and construction trade: architects, painters and sculptors - skilled professionals whose task was to rebuild a modest fortified castle into a palace worthy of a great magnate. Together with architectural development, following the example of other magnates, J. Branicki desired to make his town a center of cultural life. In order to provide a musical setting to court celebrations, he started to organize a court ensemble and a music theater. That was the reason for bringing from Italy, France and Vienna outstanding opera and ballet artists, who were to provide a nucleus for a newly created music theater. Some of them resided in Bialystok temporarily whereas the others became permanently connected with the Bialystok court. After Hetman Jan Klemens Branicki's death, some foreigners left Bialystok and never came back there.

In the second half of the 18th century, foreign visitors to the city were mainly tourists. A marvelous garden and palace design attracted tourists who were mostly seeking aesthetic sensations.
\end{abstract}

\section{Иностранцы в Белостоке в восемнадцатом веке}

\section{Резюме}

Иностранцы в Белостоке появились в начале восемнадцатого века. Инициатором их прибытия в Белосток был владелец этого маленького городка, Ян Клеменс Браницкий. Первыми, в главной мере, прибыли сюда ремесленники, специалисты в области строительного ремесла - архитекторы, маляры и скульпторы - специалисты, задачей которых была перестройка скромного оборонительного замка в достойный дворец великого магната. Вместе с архитектурным развитием Браницкий захотел, по образцу других магнатов, сделать со своего города центр культурной жизни. Чтобы обеспечить музыкальное оформление придворных торжеств, Браницкий начал организацию придворной капеллы и музыкального театра. Для этого он 
призвал, главным образом, из Италии, Франции и Вены выдающихся артистов оперы и балета, которые должны были составлять костяк вновь создаваемого музыкального театра. Часть из них жила в Белостоке временно, некоторые связались с белостокским двором навсегда. После смерти гетмана Яна Клеменса Браницкого часть иностранцев безвозвратно покинула Белосток.

Во второй половине восемнадцатого века иностранцы приезжали, главным образом, в качестве туристов. Великолепный садово-дворцовый комплекс привлекал туристов, ищущих, главным образом, эстетических впечатлений. 